\title{
Nutrients input into Ekulu River, Nigeria: Implications on Algal Bloom
}

\author{
Uzochukwu Cornelius Ugochukwu Onyechi Henry Onuora Amaka Lynda Onuorah \\ Shell/UNN Centre for Environmental Management \& Control, \\ University of Nigeria, Enugu Campus, Nigeria
}

\begin{abstract}
This study investigated the potential of nutrients input into Ekulu river to cause unwanted growth of algae that could adversely affect the aquatic ecosystem. The concentrations of nitrogen, silicon and phosphorus in the water column of Ekulu river were determined in addition to determining the $\mathrm{pH}$, electrical conductivity, total dissolved solids, total organic carbon, dissolved oxygen, biochemical oxygen demand and chemical oxygen demand following standard procedure by APHA (1998). The results show that there was increase in concentration of phosphorus, nitrogen and silicon in the rainy season. The N/P ratios varied from 6.2-15.7 indicating the possibility of nitrogen being the limiting nutrient as ratio values are less than the optimum value of 16 . The $\mathrm{Si} / \mathrm{N}$ ratio for both dry and wet seasons varied from 2.7- 9.1 indicating that $\mathrm{Si}$ input into the river is adequate and favourable to the growth and development of diatoms rather than non-diatom phytoplankton species such as dinoflagellates. Consequently, there is no significant risk of eutrophication at the present level of nutrients and silicon in Ekulu river.
\end{abstract}

Keywords: Nutrients; River; Eutrophication; Diatoms; Phtoplankton.

DOI: $10.7176 / \mathrm{JEES} / 9-1-09$

\section{INTRODUCTION}

Anthropogenic activities such as agricultural production via the use of intensive inorganic fertilizers to improve crop yield, wastewater discharge from domestic and industry sources have led to increased input of nitrogen and phosphorus into lotic systems (Pizarroa, 2010). These elements, nitrogen and phosphorus in addition to silicon are essential to marine ecosystem organismns (Ramesh et al., 2015). Soil erosion and weathering are reported as the main sources of silicon whereas agricultural run-off and domestic discharges are the main sources of nitrogen and phosphorus (Sferratore et al., 2006; Sharma et al., 2017). Recent research efforts on the role played by point and non-point sources of pollution in nutrient chemistry of rivers have been on the increase. The input of nutrients into rivers is known to be responsible for eutrophication. The effect of nutrient enrichment of rivers is more complex than that of lentic systems due to their dynamic nature. Generally speaking, same symptoms of excessive algal growth and changes in the structure of macrophytes remain typical effects of eutrophication with adverse impact on water supply. As a consequence of eutrophication, the food web of coastal marine ecosystems undergoes huge structural changes that are observable in the structure of benthic communities (Lim et al., 2006). These changes also translate to a decline in the population of zooplanktons that in-turn affect commercial production of fishes (Rousseau et al., 2000). The enrichment of nitrogen appears to be derived from dissolved nutrients in the water column whereas phosphorus enrichment is associated with both water column nutrients and nutrients bound to sediments. It has been known for a very long time that nutrient enrichment alone may not be enough to cause eutrophication, rather it is the changes that result to a shift from the nutrient stoichiometry that may result to eutrophication (Garnier et al., 2010). The stoichiometry as proposed by Redfield et al. (1963) is: $\mathrm{N}: \mathrm{P}:$ Si molar ratios of 16:1:20. If there is enrichment into the lotic systems that is in the proportion described by Redfield et al. (1963), there would not be eutrophication problems. Under this condition, the production of new planktons is largely the production of diatomaceous species while nonsiliceous algae are only produced to the extent of regeneration. On the other hand, if $\mathrm{N}$ and $\mathrm{P}$ enrichment is in excess of the Si required by diatoms, the diatoms would be limited in growth whereas the undesirable algae species will develop leading to eutrophication problems (Humborg et al., 2008). Controls that rely on in-situ solutions cannot be as good as prevention options that are based on reducing or eliminating inputs to the river system. It is therefore logical that point source pollutants would be easier managed and controlled than non-point sources from agriculture, industry etc. By and large, it is extremely important to establish whether it is point source or non-point source or both sources that is responsible for nutrient input.

Several studies have reportedly characterized many rivers in the world with respect to their nutrient chemistry especially from countries such as the USA, Spain, India, China etc. (Liu et al., 2003; Guo et al., 2004; Falco et al., 2010; Sharma et al., 2017).

Most aquatic ecosystems in Nigeria are poorly characterized with respect to nutrient chemistry and the attendant implication on eutrophication. Ekulu river that drains through Enugu metropolis is an important lotic system that receives discharges from several anthropogenic point-source pollution sources. Till date, the authors are not aware of any study that provides information on the nutrient chemistry of Ekulu river. This study is 
therefore aimed at revealing whether or not the nutrient input to Ekulu river is such that eutrophication is a source of concern.

\section{MATERIALS AND METHODS}

\subsection{Study Area}

The study area, shown in Figure 1 is Enugu metropolis, the administrative headquarters of Enugu State, Nigeria. It is located geographically between latitude $6^{0} 21^{\prime} \mathrm{N}$ and $6^{0} 30^{\prime} \mathrm{N}$ and between longitude $7^{0} 25^{\prime} \mathrm{E}$ and $7^{0} 37^{\prime} \mathrm{E}$. The main land use of the study area is agricultural, industrial, commercial and residential. The temperature of the area ranges between 25 and $35{ }^{\circ} \mathrm{C}$ with annual rainfall of about $950 \mathrm{~mm}$. The geology of the area comprises Enugu shale which is overlain by mamu formation that is in-turn overlain by Ajali formation in quick succession (Reyment, 1965). Rainy season (April - October) and dry season (November-March) are the two seasons of the study area. This study is centered on Ekulu river which is a fast flowing perennial river that drains through the metropolis and receives waste discharges from several anthropogenic activities. Coal mine water from Onyeama mine especially during the rainy season when the mine is flooded, discharges into the Ekulu river used by nearby residents to the river for washing clothing and cars, bathing, swimming, and cooking. In this study, the Onyeama area constituted a sampling point whereas $4 \mathrm{~km}$ downstream Onyeama mine was another sampling point identified as 'Damija'. The third sampling point which is about $1 \mathrm{~km}$ downstream Damija is identified as 'The Hotel'.

The study area and sampling locations are as presented in Figure 1.

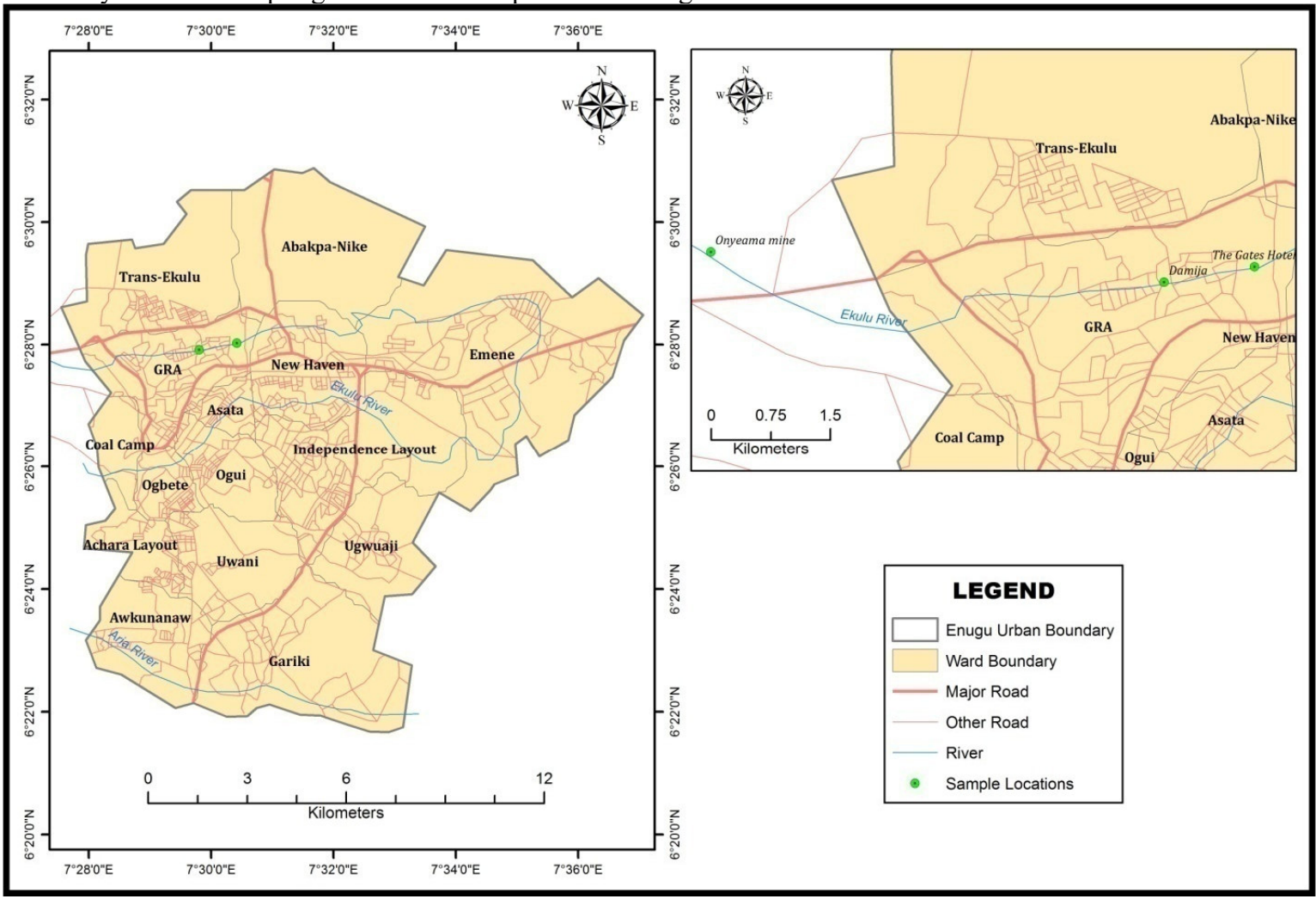

Figure 1 Map of the study area showing sampling locations, Onyeama mine (waterfall) covering a distance of about $5 \mathrm{~km}$.

\subsection{Sampling}

Samples for this study were collected in triplicates fortnightly in October, 2017 and February, 2018 to cover both the wet and dry seasons. Sampling locations are as shown in Figure 1. The sampling locations were selected to include the Onyeama zone, Damija zone and The hotel zone. Damija zone is located $2.5 \mathrm{~km}$ downstream the Onyeamal zone and $1.5 \mathrm{~km}$ upstream The Hotel zone.

Water samples were collected at the river-water column into a $1 \mathrm{~L} \mathrm{HNO}_{3}$ pre-washed polyethylene containers. Samples were held in a box filled with ice cubes so as to maintain the temperature below $4{ }^{0} \mathrm{C}$ and transported to the laboratory for analysis. 


\subsection{Laboratory Analysis}

Electrical conductivity (EC), $\mathrm{pH}$, total dissolved solids (TDS), dissolved oxygen (DO), biochemical oxygen demand (BOD), chemical oxygen demand (COD), dissolved nitrate $\left(\mathrm{NO}_{3}-\mathrm{N}\right)$, nitrite $\left(\mathrm{NO}_{2}-\mathrm{N}\right)$, ammonium $\mathrm{NH}_{4-}$ $\mathrm{N}$, phosphate $\left(\mathrm{PO}_{4}-\mathrm{P}\right)$ and silica $\left(\mathrm{SiO}_{2}-\mathrm{Si}\right)$ were analyzed following APHA 1998 standard procedure. The total organic carbon (TOC) was analyzed by means of a TOC analyzer.

\subsection{Statistical Analysis}

All statistical analysis was carried out using Minitab Version 18. Analysis of Variance (ANOVA) was used in comparing means of the values of the parameters in different locations of the river from where samples were drawn.

\section{RESULTS AND DISCUSSION}

\subsection{Values of Physico-chemical Parameters}

The values of the measured parameters are as presented in Table 1.

Table 1 Values of measured parameters (October, 2017 and February, 2018)

\begin{tabular}{|c|c|c|c|c|c|c|c|c|c|c|c|c|}
\hline \multirow{2}{*}{$\begin{array}{l}\text { River } \\
\text { Section }\end{array}$} & \multicolumn{12}{|c|}{ Values of Parameters (October, 2017) } \\
\hline & $\begin{array}{l}\mathrm{EC} \\
(\mu \mathrm{s} / \mathrm{cm})\end{array}$ & $\begin{array}{l}\text { TDS } \\
(\mathrm{mg} / \mathrm{L})\end{array}$ & $\mathrm{pH}$ & $\begin{array}{l}\mathrm{NH}_{4}-\mathrm{N} \\
(\mathrm{mg} / \mathrm{L})\end{array}$ & $\begin{array}{l}\mathrm{NO}_{3}-\mathrm{N} \\
(\mathrm{mg} / \mathrm{L})\end{array}$ & $\begin{array}{l}\mathrm{NO}_{2}-\mathrm{N} \\
(\mathrm{mg} / \mathrm{L})\end{array}$ & $\begin{array}{l}\mathrm{PO}_{4}-\mathrm{P} \\
(\mathrm{mg} / \mathrm{L})\end{array}$ & $\begin{array}{l}\mathrm{SiO}_{2}-\mathrm{Si} \\
(\mathrm{mg} / \mathrm{L})\end{array}$ & $\begin{array}{l}\text { TOC } \\
(\%)\end{array}$ & $\begin{array}{l}\text { DO } \\
(\mathrm{mg} / \mathrm{L})\end{array}$ & $\begin{array}{l}\text { BOD } \\
(\mathrm{mg} / \mathrm{L})\end{array}$ & $\begin{array}{l}\text { COD } \\
(\mathrm{mg} / \mathrm{L})\end{array}$ \\
\hline Onyeama & 19.4 & 10.1 & 6.1 & 0.18 & 0.4 & 0.005 & 0.055 & 4.0 & 0.002 & 5.0 & 0.9 & 2.1 \\
\hline Damija & 61.6 & 39.7 & 6.2 & 0.51 & 1.1 & 0.015 & 0.3 & 4.4 & 0.003 & 5.1 & 0.7 & 1.7 \\
\hline The Hotel & 64.1 & 40.8 & 6.5 & 0.44 & 0.9 & 0.013 & 0.17 & 4.4 & 0.002 & 4.9 & 0.8 & 2.1 \\
\hline \multicolumn{13}{|c|}{ Values of Parameters (February, 2018) } \\
\hline Onyeama & 15.5 & 8.2 & 5.7 & 0.07 & 0.35 & 0.0015 & 0.065 & 1.9 & 0.001 & 4.1 & 0.9 & 2.2 \\
\hline Damija & 13.3 & 7.8 & 6.3 & 0.14 & 0.35 & 0.0025 & 0.065 & 1.0 & 0.001 & 4.2 & 0.9 & 2.1 \\
\hline The Hotel & 15.4 & 8.3 & 5.9 & 0.08 & 0.2 & 0.001 & 0.02 & 2.0 & 0.001 & 4.1 & 0.8 & 1.9 \\
\hline
\end{tabular}

During the rainy season, the electrical conductivity (EC) varied from $19.4-64.1 \mu \mathrm{S} / \mathrm{cm}$ and increases as we move from the Onyeama section of the river to The Hotel (Table 1) indicating that anthropogenic activities taking place between Onyeama and The Hotel release substances into the river that dissociate to form ions capable of conducting electricity. The TDS and EC values around Onyeama are lower and significantly different from those around Damija and The Hotel during the rainy season confirming anthropogenic input of contaminants around Damija and The Hotel. However, during the dry season, there is no significant difference in the EC and TDS values for all locations indicating that the relative high input of contaminants during the rainy season could be associated with run-off.

The $\mathrm{pH}$ of the river varies from 6.2-6.5 in the rainy season but 5.7-6.3 in the dry season indicating that the river is mildly more acidic in the dry season than the rainy season (Table 1). The dilution effect of more discharge into the river during the rainy season may have accounted for why in the rainy season, the river is of lower acidity than in the dry season. The result also indicates that the water sample taken around Onyeama is more acidic than those taken from Damija and The Hotel and is most likely to be due to acid mine drainage around Onyeama.

The nitrate ion is the predominant form of Nitrogen among the other forms in both dry and rainy seasons indicating the prevalence of agricultural run-off, atmospheric precipitation, waste discharge and in-stream transformation of ammonium ion by bacteria as most probable sources of nitrogen input into the river (Sharma et al., 2017). It is unlikely that domestic sewage and/or faecal matter contributes significantly to the nitrogen input into the Ekulu river as $\mathrm{NH}_{4}-\mathrm{N}+\mathrm{NO}_{2}-\mathrm{N} / \mathrm{NO}_{3}-\mathrm{N}$ ratio is $<1.0$.

For The Hotel and Damija, there is a significant increase in the concentration of phosphate as we move from dry to rainy season most probably due to input of phosphate into the river from agricultural run-off and waste discharge.

The concentration of silica $\left(\mathrm{SiO}_{2}-\mathrm{N}\right)$ increased significantly as we move from dry season $(1.0-2.0 \mathrm{mg} / \mathrm{L})$ to rainy season $(4.0-4.4 \mathrm{mg} / \mathrm{L})$ due to increased weathering of rocks and transportation of the produced silica that take place during the rainy season by run-off. This increase is proportionate and adequately compensates for the increase in nutrients input during the rainy season and therefore silicon is not expected to limit the production of diatoms as nutrients input increases. It is therefore not expected that additional input of nutrients during the rainy season would lead to any significant growth of multi-cellular algae and higher plants.

TOC is higher in wet season than dry season for all the locations and is attributable to run-off carrying minor oil spillages to the river. 
3.2 Analysis of Ekulu River Nutrient Ratios

Table 2 Ekulu river N/P and Si/N ratios for the river sections at Onyeama, Damija and The Hotel

\begin{tabular}{lcl}
\hline \multicolumn{2}{l}{ Values for the rainy season (October, 2017) } & \\
\hline River Section & $\mathrm{N} / \mathrm{P}$ ratio & $\mathrm{Si} / \mathrm{N}$ ratio \\
Onyeama & 13.6 & 7.8 \\
Damija & 6.5 & 3.2 \\
The Hotel & 9.7 & 3.9 \\
Values for the dry season & $($ February, 2018) & 6.9 \\
Onyeama & 6.2 & 2.7 \\
Damija & 9.1 & 9.1 \\
\hline The Hotel & 15.7 & \\
\hline
\end{tabular}

3.2.1 N/P ratio around Onyeama, Damija and The Hotel

The growth and development of phytoplanktons can only be sustained by the availability of nutrients such as nitrogen and phosphorus including silicon at the appropriate ratios (Redfield et al., 1963). This ratio as given by Redfield et al. (1963) is N/P = 16:1 meaning that N/P ratio significantly different from 16:1 will indicate that either nitrogen or phosphorus is in limited supply and therefore will be the element limiting the growth and development of the phytoplanktons. During the rainy season, growth and development of the phytoplanktons around Damija and The Hotel sections of the river is likely to be limited by nitrogen as the N/P ratio is significantly lower than 16 . The N/P ratio at Onyeama is not significantly different from Redfield et al. (1963) value of 16. During the dry season, N/P ratios at Onyeama and Damija are significantly lower than 16 indicating that $\mathrm{N}$ will limit the growth and development of phytoplanktons unlike at The Hotel where N/P ratio approximates the optimum value of 16.

\subsection{2 $\mathrm{Si} / \mathrm{N}$ ratio}

The molar ratio of $\mathrm{Si} / \mathrm{N}$ is used in predicting the growth of diatoms vis-a-vis other problematic non-diatom phytoplankton species such as dinoflagellates. Turner et al. (2003) found that $\mathrm{Si} / \mathrm{N}$ molar ratio of 1 and above will favour the growth and development of diatoms whereas $\mathrm{Si} / \mathrm{N}$ molar ratio of less than one will favour nondiatoms such as dinoflagellates that can result to algal bloom. The $\mathrm{Si} / \mathrm{N}$ ratio for all the locations in this study is above one indicating that there is low chance of algal bloom that could result from eutrophication.

\section{Conclusion}

The concentrations of nitrogen, phosphorus and silicon were determined in some sections of Ekulu river namely, Onyeama, Damija and The Hotel in order to establish the potential for eutrophication. Higher concentrations of the nutrients during the rainy season confirm seasonal effects towards elevation of the concentration values. The input of nutrients into Ekulu river is most likely to come from agricultural run-off, waste discharge and in-stream transformation of ammonium ion by bacteria. Domestic sewage or faecal matter does not contribute significantly to the input of nitrogen into the Ekulu river. The concentrations of the nutrients which are higher in the rainy season than the dry season confirm the significant contribution of agricultural run-off. The various sections of Ekulu river studied have adequate concentration of silicon required for the growth and development of diatoms rather than dinoflagellates. Generally, there is no risk of eutrophication in the studied sections of Ekulu river going by the present concentration levels of the nutrients.

\section{Reference}

APHA (American Public Health Association) 2012. Standard methods for the examination of water and waste water. $22^{\text {nd }}$ Edition, Washington.

Falco, S., Niencheski, L.F., Rodilla, M., Romero, I., Gonzalek, del Rio J., Sierra, J.P., Mosso, C. 2010. Nutrient flux and budget in the Ebro estuary. Estuarine, Coastal and Shelf Science, 87, 92-107.

Garnier, J., Beusen, A., Thieu, V., Billen, G., Bouwman, L. 2010. N:P:Si nutrient export ratios and ecological consequences in coastal seas evaluated by the ICEP approach. Global Biogeochemical Cycles, 24. DOI: 10.1029/2009GB003583.

Guo, L., Zhang, J.Z., Gueguen, C. 2004. Speciation and fluxes of nutrients (N, P, Si) from the Upper Yukon River. Global Biogeochemical Cycles, 18, GP1038. 12 pp.

Humbong, C. Smedberg, E., Medina, M.R., Morth, C.-M. 2008. Changes in dissolved silicate loads to the Baltic Sea. The effects of Lakes and reservoirs. Journal of Marine Systems, 73, 223-235.

Lim, H. -S, Diaz, R.J., Hong, J.-S., Schaffner, L.C. 2006. Hypoxia and benthic community recovery in Korean coastal waters, Marine Pollution Bulletin, 52, 1517-1526.

Liu, S.M., Zhang, J., Chen, H.T., Wiu, Y., Xiong, H., Zhang, Z.F. 2003. Nutrients in the Changjiang and its tributaries. Biogeochemistry, 62, 1-18.

Pizarroa, J., Vergaraa, P.M., Rodrigueza, J.A., Sanhuezaa, P.A., Castrob, S.A. 2010. Nutrients dynamics in the 
main river basins of the centre-southern region of Chile. Journal of Hazardous Materials, 175, 608-613.

Ramesh, R., Robin, R.S. and Purvaya, R. 2015. An inventory on the phosphorus flux of major Indian rivers. Special Section: Sustainable Phosphorus Management. Current Science, 10, 1294-1299.

Redfield, A.C., Ketchum, B.H., Richards, F.A. 1963. The influence of organisms on the composition of seawater. The Sea, 2, Willey, New York. Pp 26-77.

Rousseau, V., Becquevort, S., Parent, J.-Y. Gasparini, S., Dano, M. -H., Tackx, M., Lancelot, C. 2000. Trophic efficiency of the planktonic food web in a coastal ecosystem dominated by phaeocystis colonies. Journal of Sea Research, 43, 357-372.

Sferratore A, Garnier J, Billen G, Conley DI, Pinaul S. 2006. Diffuse and point sources of silica in the Seine River watershed. Environ Sci Technol., 40(21):6630-5.

Sharma, S., Jha, P.K., Ranjan, M.R., Singh, U.K., Kumar, M., Jindal, T. 2017. Nutrient Chemistry of River Yamuna, India. Asian Journal of Water, Environment and Pollution, 14 (2), 61-70.

Turner, R.E., Rabalais, N.N., Justic, D., Dortch, Q. 2003. Global patterns of dissolved N, P and Si in large rivers. Biogeochemistry, 64, 297-313. 